\title{
EFEKTIVITAS KONSELING KELOMPOK DENGAN MEMANFAATKAN MODEL UNTUK MENINGKATKAN KEDISIPLINAN SISWA KELAS XI MIA 3 SMA NEGERI 8 SURAKARTA SEMESTER II TAHUN 2014/2015
}

\author{
Mawarto \\ mawarto@gmail.com \\ SMA Negeri 8 Surakarta
}

\begin{abstract}
ABSTRAK
Penelitian ini bertujuan untuk meningkatkan disiplinan siswa melalui konseling kelompok. Hasil yang diharapkan adalah meningkatnya kedisiplinan siswa dalam mengikuti bimbingan klasikal. Subjek penelitian mencakup siswa SMA Negeri 8 Surakarta tahun Pelajaran 2014/2015 sejumlah 25 siswa, dibagi menjadi 4 kelompok konseling, masing-masing kelompok terdiri dari 6 anggota. Penelitian ini hanya memeriksa dan melaporkan masalah yang terkait dengan kedisiplinan dalam mengikuti bimbingan klasikal. Jenis penelitian yang digunakan adalah Penelitian Tindakan Bimbingan dan Konseling. Teknik analisis penelitian dilakukan dengan cara mengukur hasil sesudah treatmen dikurangi sebelum treatmen dibagi sebelum treatmen kali $100 \%$. Hasil analisis menunjukkan bahwa kedisiplinan siswa dalam mengikuti bimbingan klasikal dari kondisi awal, siklus I, dan siklus II meningkat. Hal ini ditampilkan pada kedisiplinan siswa dalam kondisi awal ada 52 jenis pelanggaran kedisiplinan dan siklus I ada 29 pelanggaran kedisiplinan dan setelah siklus II tinggal 6 pelanggaran kedisiplinan yang tidak memenuhi kedisplinan dalam mengikuti bimbingan klasikal. Tindakan siklus I menunjukan hasil 45,75\% sedangkan tindakan siklus II menunjukan hasil $77,5 \%$. Menurut Goodwin dan Coates bila perubahan mencapai 50\% maka strategi ini dipandang berhasil. Kesimpulan dari penelitian ini adalah bahwa konseling kelompok dapat meningkatkan kedisiplinan siswa SMA Negeri 8 Surakarta semester II tahun pelajaran 2014/2015. Saran kepada rekan-rekan guru BK untuk lebih meningkatkan kualitas layanan bimbingan dan konseling khususnya konseling kelompok, sehingga memiliki kesiapan dan jika ada kesulitan dan atau kelemahan dalam pelaksanaannya dapat diatasi dengan baik lewat budaya penelitian bimbingan dan konseling.
\end{abstract}

Kata kunci: konseling kelompok, model, kedisiplinan siswa

\section{PENDAHULUAN}

Kedisiplinan merupakan kata yang ringan diucapkan namun sukar untuk dapat dilakukan dalam bentuk tindakan, seperti halnya yang terjadi pada anak-anak didik di masa sekarang ini. Kedisiplinan mungkin sebatas pada ucapan mereka saja, namun dalam bentuk implementasi tindakan masih ada saja anak-anak yang tidak disiplin. 
Seperti halnya yang terjadi di SMA Negeri 8 Surakarta tempat penulis bertugas sebagai guru masih saja dijumpai anak-anak yang tidak disiplin sebagai siswa di sekolah. Adapun wujud dari kurangnya kedisiplinan tersebut dapat dilihat dari tindakan-tindakan 1) suka ramai/berbicara sendiri jika diberikan layanan informasi 2) mengabaikan tugas yang diberikan guru BK 3) kurangnya berpakaian yang tidak rapi yang ditunjukkan dengan tidak lengkapnya atribut sekolah yang dipakai dan, 4) seringnya datang terlambat masuk sekolah.

Dari permasalahan yang ditimbulkan karena tindakan yang kurang disiplin oleh siswa seperti suka ramai sendiri, mengabaikan tugas yang diberikan, berpakaian yang kurang rapi dan sering terlambat maka mengakibatkan pemberian pelajaran menjadi tidak maksimal sehingga diperlukan adanya teknik tertentu untuk meningkatkan kedisiplinan.

Sesuai dengan program bimbingan dan konseling di sekolah ditegaskan dalam buku pedoman dari Depdikbud bahwa penyelenggaraan bimbingan konseling dalam perkembangannya sampai sekarang dirinci menjadi 4 bidang yaitu : (1) bimbingan pribadi, (2) bimbingan sosial, (3) bimbingan belajar, (4) bimbingan karier. Disamping 4 bidang bimbingan tersebut ada 9 jenis layanan yaitu: (1) layanan orientasi, (2) layanan informasi, (3) layanan penempatan dan penyaluran, (4) layanan penguasaan konten, (5) layanan konseling perorangan, (6) bimbingan kelompok, (7) layanan konseling kelompok, (8) layanan konsultasi dan (9) layanan mediasi.

Berdasar kesembilan jenis layanan tersebut, salah satunya adalah layanan konseling kelompok. Dalam penjelasan tentang konseling kelompok dirumuskan sebagai berikut: konseling kelompok adalah proses konseling yang dilakukan dalam situasi kelompok, dimana konselor berinteraksi dengan konseli dalam bentuk kelompok yang dinamis untuk memfasilitasi perkembangan individu dan atau membantu individu dalam mengatasi masalah yang dihadapi secara bersama-sama. Dengan demikian tampaklah bahwa layanan konseling kelompok dimaksudkan untuk membantu mengatasi masalah yang dihadapi siswa. Akan tetapi mengingat bahwa anak usia SMA adalah siswa remaja menginjak dewasa yang memiliki kondisi berkembang, maka dalam berperilaku ia berusaha untuk menyalurkan kekuatan yang dimilikinya. Oleh karena itu, siswa-siswi sering melanggar tata peraturan, khususnya kurang disiplin dalam mengikuti layanan bimbingan.klasikal.

Dari apa yang telah diuraikan di atas, penulis sebagai guru bimbingan konseling merasa ikut bertanggung jawab atas hal tersebut. Maka dari itu, penulis akan mencoba melakukan penelitian ilmiah dalam bentuk penelitian tindakan bimbingan konseling sebagai upaya untuk meningkatkan kedisiplinan siswa melalui konseling kelompok. 
Efektivitas Konseling Kelompok Dengan Memanfaatkan Model Untuk Meningkatkan Kedisiplinan Siswa Kelas XI MIA 3 SMA Negeri 8 Surakarta Semester II Tahun 2014/2015 (Mawarto)

\section{KAJIAN PUSTAKA DAN HIPOTESIS TINDAKAN}

\section{Pengertian Konseling Kelompok}

Konseling kelompok menurut Pauline Harrison (2002) adalah konseling yang terdiri dari $4-8$ konseli yang bertemu dengan $1-2$ konselor. Dalam prosesnya, konseling kelompok dapat membicarakan beberapa masalah seperti kemampuan dalam membangun hubungan dan komunikasi, pengembangan harga diri, dan keterampilan-keterampilan dalam mengatasi masalah.

Juntika Nurihsan (2006: 24) mengatakan bahwa konseling kelompok adalah suatu bantuan kepada individu dalam situasi kelompok yang bersifat pencegahan dan penyembuhan, serta diarahkan pada pemberian kemudahan dalam perkembangan dan pertumbuhannya.

Berdasarkan pendapat di atas bahwa konseling kelompok adalah proses konseling yang dilakukan dalam situasi kelompok, dimana konselor berinteraksi dengan konseli dalam bentuk kelompok yang dinamis untuk memfasilitasi perkembangan individu dan atau membantu individu dalam mengatasi masalah yang dihadapi secara bersama-sama. Konseling kelompok bersifat memberikan kemudahan dalam pertumbuhan dan perkembangan individu, dalam arti bahwa konseling kelompok memberikan dorongan dan motivasi kepada individu untuk membuat perubahan-perubahan dengan memanfaatkan potensi secara maksimal sehingga dapat mewujudkan diri.

Fungsi layanan konseling kelompok Juntika Nurihsan (2006: 24) mengatakan bahwa layanan konseling kelompok bersifat pencegahan dan penyembuhan. Menurut Edi Kurnanto (2013: 9) mengatakan bahwa fungsi layanan konseling kelompok ada dua yaitu fungsi layanan kuratif dan preventif. Kuratif yaitu layanan yang diarahkan untuk mengatasi persoalan yang dialami individu, sedangkan preventif diarahkan mencegah terjadinya persoalan pada diri individu.

Konseling kelompok bersifat penyembuhan alam pengertian membantu individu untuk dapat keluar dari persoalan yang dialaminya dengan cara memberikan kesempatan, dorongan, juga pengarahan kepada individu untuk mengubah sikap danperilakunya agar selaras dengan lingkungannya. Penyembuhan yang dimaksud di sini adalah penyembuhan bukan persepsi pada individu yang sakit karena pada prinsipnya objek konseling adalah individu yang normal, bukan individu yang sakit secara psikologis.

Brown (2009 mengatakan bahwa ketika pemimpin sepenuhnya memahami tujuan dari kelompok, lebih mudah baginya untuk memutuskan hal-hal seperti ukuran, keanggotaan, pangjang sesi, dan jumlah sesi dalam kelompok. Jacob, at al (2012:57) mengatakan bahwa ketika seorang pemimpin kelompok belum jelas tentang tujuan kelompok yang dipimpinnya, maka ada kecenderungan kelompok tersebut akan sering membingungkan, membosankan, atau tidak produktif atau 
pemimpin tidak mengikuti tujuan yang dinyatakan. Selain itu, tujuan kelompok dapat berubah sebagaimana perkembangan yang terjadi pada kelompok. Jika konselor menguasai proses klarifikasi tujuan, berikutnya yang penting dari aspek kepemimpinan kelompok yang efektif adalah perencanaan.

\section{Pengertian Disiplin Siswa}

Secara etimologi, kata disiplin berasal dari bahasa latin, yaitu disciplina dan discipulus yang berarti perintah dan murid. Disiplin adalah perintah yang diberikan oleh orang tua atau guru kepada murid. Perintah tersebut diberikan agar ia melakukan apa yang diinginkan oleh orang tua dan guru. Webster's New World Dictionary mendefinisikan disiplin sebagai latihan untuk mengendalikan diri, karakter dan keadaan secara tertib serta efisien. Sementara dalam Kamus Besar Bahasa Indonesia, terdapat tiga arti disiplin yaitu tata tertib, ketaatan, dan bidang studi (Wiyani, 2013:41)

Dari pengertian disiplin secara etimologi, disiplin adalah suatu keharusan dimana murid harus melakukan suatu perbuatan atau tindakan sesuai perintah orang tua atau guru. Harapan orang tua atau guru, murid patuh dengan perintah tersebut.

Bagi siswa disiplin bersifat arbitrair artinya adalah suatu konformitas pada tuntutan eksternal, namun bila dilakukan dalam suatu suasana emosional yang positif, menjadi proses pendidikan yang menimbulkan keikhlasan dari dalam dirinya untuk berbuat sesuai peraturan, tanpa merasa dirinya takut atau terpaksa. Dengan demikian tidak terjadi "disiplin bangkai" (cadaveric discipline), yaitu kepatuhan mati yang ditaati karena takut dan tanpa pikir atau tanpa keikhlasan (Semiawan, 2009).

Disiplin dapat diartikan sebagai suatu keadaan tertib dimana orang-orang yang tergabung dalam suatu sistem tunduk pada peraturan-peraturan yang ada dengan senang hati. Disiplin ini merupakan kesadaran diri yang muncul dari batin terdalam untuk mengikuti dan menaati peraturan-peraturan, nilai-nilai dan hukumhukum yang berlaku dalam suatu lingkungan tertentu. Kesadaran itu antara lain, kalau dirinya disiplin baik maka akan memberi dampak yang baik bagi keberhasilan dirinya pada masa depannya (Mulyasa, 2003).

Mendidik disiplin pada siswa merupakan proses yang harus dilakukan sepanjang waktu. Hal ini akan membentuk suatu kebiasaan sehingga seorang individu akan dengan mudah untuk melakukannya.

Pengaruh disiplin pada siswa

Adapun penerapan tipe-tipe disiplin ini memberi dampak yang cukup nyata bedanya. Pengaruh penerapan disiplin pada siswa, meliputi beberapa aspek, misalnya:

a. Pengaruh pada perilaku 
Efektivitas Konseling Kelompok Dengan Memanfaatkan Model Untuk Meningkatkan Kedisiplinan Siswa Kelas XI MIA 3 SMA Negeri 8 Surakarta Semester II Tahun 2014/2015 (Mawarto)

Siswa yang mengalami disiplin yang keras, otoriter, biasanya akan sangat patuh bila di hadapan orang-orang dewasa, namun sangat agresif terhadap teman sebayanya. Sedangkan siswa yang orang tuanya lemah akan cenderung mementingkan diri sendiri, tidak menghiraukan hak orang lain, agresif dan tidak sosial. Siswa yang dibesarkan dengan disiplin yang demokratis akan lebih mampu belajar mengendalikan perilaku yang salah dan mempertimbangkan hakhak orang lain (Leman, 2009).

b. Pengaruh pada sikap

Baik siswa yang dibesarkan dengan cara disiplin otoriter maupun dengan cara yang lemah, memiliki kecenderungan untuk membenci orang yang berkuasa. Siswa yang diperlakukan dengan cara otoriter merasa mendapat perlakuan yang tidak adil. Sedangkan siswa yang orang tuanya lemah merasa bahwa orang tua seharusnya memberitahu bahwa tidak semua orang dewasa mau menerima perilakunya. Disiplin yang demokratis akan menyebabkan kemarahan sementara, tetapi kemarahan ini bukanlah kebencian. Sikap-sikap yang terbentuk sebagai akibat dari metode pendidikan siswa cenderung menetap dan bersifat umum, tertuju kepada semua orang yang berkuasa (Leman, 2009).

c. Pengaruh pada kepribadian

Proses-proses psikososial melibatkan perubahan-perubahan dalam aspek perasaan, emosi, dan kepribadian individu serta cara yang bersangkutan berhubungan dengan orang lain. Dengan demikian perkembangan identitas diri (self identity) dan krisis-krisis yang menyertainya serta perkembangan cara dan pola hubungan dengan anggota keluarga, teman sebaya, guru-guru, dan yang lainnya. Semakin banyak siswa diberi hukuman fisik, semakin siswa menjadi keras kepala, dan negatifistik. Ini memberi dampak penyesuaian pribadi dan sosial yang buruk, yang juga memberi ciri khas dari siswa yang dibesarkan dengan disiplin yang lemah. Bila siswa dibesarkan dengan disiplin yang demokratis, ia akan mampu memiliki penyesuaian pribadi dan penyesuaian sosial yang terbaik (Arisandi, 2011).

Persepsi yang sering keliru adalah pengertian istilah pemberian hadiah. Kadang orang tua beranggapan bahwa memberikan hadiah selalu berupa memberi mainan, permen, coklat, atau hadiah lain yang berupa benda. Sebenarnya hadiah juga dapat berupa bukan benda, misalnya berupa pengakuan atau pujian pada siswa. Para orang tua yang menggunakan cara disiplin demokratis, tidak mau banyak memberi hadiah berupa benda. Mereka khawatir hal ini akan memanjakan siswa atau takut cara ini dianggap sebagai bentuk penyuapan yang merupakan teknik disiplin yang buruk (Leman, 2009).

Pelanggaran berupa bentuk ringan dari ketidaktaatan pada aturan atau perbuatan yang keliru sangat sering terjadi pada masa prasekolah. Pelanggaran ini disebabkan oleh tiga hal. Pertama, ketidaktahuan siswa bahwa perilakunya itu 
tidak baik atau tidak dibenarkan. Siswa mungkin saja sudah diberi tahu berulang kali dan ia pun hafal kata-kata aturannya itu, tetapi ia tidak mengerti konsep yang dikandung dari aturan itu, dan kapan ia harus menerapkannya. Sebagai contoh, siswa bisa mengerti bahwa mencuri adalah tidak boleh, tetapi ia belum tentu tahu bahwa mencontek juga termasuk mencuri.

Hal kedua yang sering juga menjadi penyebab siswa melanggar adalah siswa belajar bahwa sengaja tidak patuh dalam hal yang kecil-kecil umumnya akan mendapatkan perhatian yang lebih besar daripada perilaku yang baik. Jadi kadang siswa yang merasa diabaikan, demi menarik perhatian orang tuanya, sengaja berbuat salah dengan harapan akan memperoleh perhatian lebih. Dan ketiga, pelanggaran dapat disebabkan oleh kebosanan. Bila siswa tidak memiliki kegiatan untuk mengisi waktu luang, maka kadang kala siswa ingin membuat kehebohan. Atau kadang bisa juga ia hendak menguji kekuasaan orang dewasa dengan melihat seberapa jauh ia dapat melakukan sesuatu tanpa dihukum (Leman, 2009).

\section{Hipotesis Tindakan}

Dari uraian di atas, maka dalam penelitian ini penulis dapat menyampaikan sebuah hipotesis tindakan yakni melalui konseling kelompok diduga dapat meningkatkan kedisiplinan siswa

\section{METODE PENELITIAN}

Penelitian ini dilakukan di Sekolah Menengah Atas Negeri 8 Surakarta, Kota Surakarta Tahun Pelajaran 2014/2015. Pemilihan tempat ini didasarkan karena penulis bertugas sebagai tenaga pengajar pada instansi tersebut, sehingga penulis merasa bertanggung jawab untuk ikut mengembangkan sekolah tersebut.

Subyek atau individu yang dikenai tindakan dalam penelitian ini adalah siswa kelas XI MIA 3 SMA Negeri 8 Surakarta Tahun Pelajaran 20142015 dengan jumlah siswa 25 orang anak. Penulis sengaja memilih karena dalam kelas ini terlihat bahwa kedisiplinannya kurang dibandingkan dengan kelas lain, dimana sumber ini penulis dapatkan dari informasi dan pengamatan selama ini.

Dalam penelitian ini variabel yang diteliti mencakup tiga variabel yaitu variabel input, variabel output, dan variabel proses. Variabel input dalam penelitian ini adalah masalah kurangnya disiplin pada siswa kelas XI MIA 3 SMA Negeri 8 Surakarta. Variabel inilah yang menjadi kondisi atau perilaku yang akan diubah. Adapun variabel prosesnya berupa tindakan yang ditempuh untuk mengubah variabel input tersebut. Dalam hal ini tindakan yang dimaksud adalah memberikan bantuan melalui konseling kelompok untuk mengatasi siswa yang bertindak kurang disiplin. Sedangkan variabel output yang diharapkan adanya perubahan perilaku menjadi disiplin. 
Efektivitas Konseling Kelompok Dengan Memanfaatkan Model Untuk Meningkatkan Kedisiplinan Siswa Kelas XI MIA 3 SMA Negeri 8 Surakarta Semester II Tahun 2014/2015 (Mawarto)

Rencana tindakan yang akan dilakukan dengan tindakan dua siklus atau dua kali langkah yang akan dijadikan pedoman dalam melaksanakan tindakan yang akan dilakukan. Rencana tindakan dimaksudkan untuk memberikan gambaran yang jelas mengenai prosedur yang akan dilakukan dalam tindakan, agar tindakan yang dilakukan dapat mencapai tujuan yang ditetapkan. Tindakan yang ditempuh dimaksudkan untuk mengubah kondisi atau perilaku siswa yang kurang disiplin dan sikap siswa yang kurang memiliki kekuatan dalam hal kemandirian dalam bertindak dimana tindakan itu mencakup perencanaan, implementasi tindakan, observasi dan interprestasi serta analisis refleksi.

Alat pengumpulan data yang digunakan adalah non tes dengan alat pengumpulan data :

Wawancara dengan melakukan wawancara klasikal di kelas XI MIA 3.

Observasi dengan melakukan pengamatan selama siswa di sekolah.

Indikator kinerja atau ukuran keberhasilan yang menjadi target penelitian ini adalah :

1. Siswa dapat bersikap disiplin dalam bertindak.

2. Melakukan perintah / tugas dari guru yang ada baik secara tertulis maupun tidak tertulis.

3. Berpakaian yang rapi dan menggunakan atribut yang lengkap .

4. Tidak datang terlambat masuk sekolah.

Keberhasilan teknik ini dapat diukur dengan perhitungan sebagai berikut:

(Post rate-Based rate) $x 100 \%=$ Percentage Change

Base - rate

(Goodwin dan Coates, 1976 : 57)

Bila perubahan mencapai 50\% maka strategi ini dipandang berhasil.

Keterangan :

(Sesudah treatment - Sebelum treatment))

Sebelum treatment

\section{HASIL PENELITIAN DAN PEMBAHASAN}

\section{Siklus I}

Kondisi awal pelaksanaan tindakan dilakukan pada bulan April - Juni 2015.

Langkah-langkah yang ditempuh dalam pelaksanaan tindakan yaitu:

a) Mengidentifikasi siswa yang bersikap kurang disiplin melalui observasi. Dan wawancara pada waktu guru mengajar di kelas tersebut.

b) Menentukan alternatif tindakan yang efektif untuk mengatasi masalah kurangnya kedisiplinan siswa kelas XI MIA 3 SMA Negeri 8 Surakarta, 
dengan melaksanakan program Konseling Kelompok. Hal ini dilaksanakan pada waktu jam pelajaran Bimbingan dan Konseling selama satu jam pelajaran.

c) Melaksanakan bimbingan klasikal pada subyek penelitian yakni kelas XI MIA 3 SMA Negeri 8 Surakarta.

Adapun Matrik Tindakan I dengan Konseling Kelompok dapat dilihat pada tabel berikut.

Tabel 2 : Matrik Tindakan I dengan Konseling Kelompok

\begin{tabular}{|c|c|c|c|}
\hline $\begin{array}{c}\text { Rincian } \\
\text { Kegiatan } \\
\end{array}$ & $\begin{array}{c}\text { Peran } \\
\text { Pembimbing }\end{array}$ & Peran Subyek & Hasil \\
\hline $\begin{array}{l}\text { Mengadakan } \\
\text { pendekatan } \\
\text { secara klasikal. }\end{array}$ & $\begin{array}{l}\text { Menciptakan } \\
\text { suasana harmonis, } \\
\text { hangat, di dalam } \\
\text { kelas. }\end{array}$ & $\begin{array}{l}\text { Subyek menerima } \\
\text { pembimbing dengan } \\
\text { penuh senang. }\end{array}$ & $\begin{array}{l}\text { Terciptanya } \\
\text { hubungan yang } \\
\text { harmonis dan } \\
\text { hangat di kelas. }\end{array}$ \\
\hline $\begin{array}{l}\text { Mengungkap } \\
\text { masalah yang } \\
\text { dihadapi } \\
\text { subyek. }\end{array}$ & $\begin{array}{l}\text { Menjelaskan } \\
\text { tentang masalah } \\
\text { subyek. }\end{array}$ & $\begin{array}{l}\text { Subyek menanggapi } \\
\text { apa yang } \\
\text { disampaikan } \\
\text { pembimbing dan } \\
\text { menyadarinya. }\end{array}$ & $\begin{array}{l}\text { Masalah subyek } \\
\text { terungkap. }\end{array}$ \\
\hline $\begin{array}{l}\text { Mengungkap } \\
\text { faktor } \\
\text { penyebab } \\
\text { terjadinya } \\
\text { masalah. }\end{array}$ & $\begin{array}{l}\text { Bertanya tentang } \\
\text { hal yang berkaitan } \\
\text { dengan masalah } \\
\text { dengan masalah } \\
\text { yang ada di kelas. }\end{array}$ & $\begin{array}{l}\text { Subyek bercerita } \\
\text { tentang kejadian } \\
\text { timbulnya } \\
\text { permasalahan di } \\
\text { kelas. }\end{array}$ & $\begin{array}{l}\text { Terungkap latar } \\
\text { belakang } \\
\text { masalah subyek. }\end{array}$ \\
\hline $\begin{array}{l}\text { Menerapkan } \\
\text { konseling } \\
\text { kelompok. }\end{array}$ & $\begin{array}{l}\text { Memberikan } \\
\text { arahan kepada } \\
\text { subyek }\end{array}$ & $\begin{array}{l}\text { Subyek menyadari } \\
\text { mempunyai } \\
\text { kedisiplinan untuk } \\
\text { berubah. }\end{array}$ & $\begin{array}{l}\text { Kesediaan } \\
\text { subyek untuk } \\
\text { meningkatkan } \\
\text { disiplin yang } \\
\text { lebih baik. }\end{array}$ \\
\hline $\begin{array}{l}\text { Mengakhiri } \\
\text { pertemuan. }\end{array}$ & $\begin{array}{l}\text { Menutup konseling } \\
\text { kelompok, } \\
\text { menyimpulkan dan } \\
\text { menawarkan } \\
\text { pertemuan } \\
\text { selanjutnya. }\end{array}$ & $\begin{array}{l}\text { Subyek menerima } \\
\text { tawaran untuk } \\
\text { pertemuan } \\
\text { selanjutnya. }\end{array}$ & $\begin{array}{l}\text { Subyek } \\
\text { mempunyai } \\
\text { keinginan untuk } \\
\text { mengatasi } \\
\text { masalah } \\
\text { kedisiplinannya. }\end{array}$ \\
\hline
\end{tabular}

Sesuai dengan teknik konseling yang digunakan yaitu Konseling Kelompok, maka pelaksanaan konseling dilakukan secara berkelompok. Pada konseling ini menekankan pada aspirasi atau harapan subyek agar dapat berdisiplin dan menyadari apa yang telah dilakukan oleh subyek adalah tindakan yang kurang baik dan perlu dirubahnya.

Sesuai dengan topik penelitian ini, maka treatment yang diberikan untuk mengatasi masalah, siswa dipilih pendekatan Konseling Kelompok. Dalam konseling ini langkah yang ditempuh sebagai berikut: 
Efektivitas Konseling Kelompok Dengan Memanfaatkan Model Untuk Meningkatkan Kedisiplinan Siswa Kelas XI MIA 3 SMA Negeri 8 Surakarta Semester II Tahun 2014/2015 (Mawarto)

1) Analisis

Identifikasi tingkah laku pada sampel penelitian sesuai dengan konsep konseling kelompok, atas dasar dari hasil pengamatan dan perolehan dari hasil temuan di kelas peneliti menemukan kelas yang memiliki tingkat kedisiplinnnya yang kurang baik.

Dalam Konseling kelompok ini penulis mengidentifikasikan suatu tindakan yang termasuk dalam kategori kurangnya kedisiplinan yang terjadi pada kelas XI MIA 3 yakni dengan bentuk tindakan-tindakan yang merugikan bagi siswa itu sendiri antara lain kurang memperhatikannya siswa pada waktu diberikan materi pelajaran kurang disiplin, adanya siswa yang berpakaian kurang rapi, adanya siswa yang seringkali mengabaikan tugas atau anjuran guru dan adanya siswa yang sering terlambat masuk sekolah.

2) Sintesis

Berdasarkan data-data yang diperoleh dapat digambarkan lebih jelas dengan tabel 3 berikut.

Tabel 3. Jumlah Penyimpangan Perilaku yang Akan Dirubah

\begin{tabular}{|l|l|l|}
\hline No & Jumlah Siswa & \multicolumn{1}{|c|}{$\begin{array}{c}\text { Penyimpangan Perilaku yang Akan } \\
\text { Dirubah }\end{array}$} \\
\hline 1. & $\begin{array}{l}12-18 \text { siswa } \\
\text { yang melakukan } \\
\text { tindakan kurang } \\
\text { disiplin }\end{array}$ & $\begin{array}{l}\text { Sikap yang kurang disiplin yakni siswa } \\
\text { berbicara sendiri pada waktu diberikan } \\
\text { materi pelajaran, siswa yang berpakaian } \\
\text { kurang rapi, siswa yang mengabaikan } \\
\text { tugas guru jika diberikan tugas dan sering } \\
\text { terlambat masuk sekolah. }\end{array}$ \\
\hline
\end{tabular}

3) Diagnosis

Menurut hasil analisis dan sintesis maka dalam langkah diagnosis peneliti melakukan identifikasi untuk mengambil kemungkinan masalah dan penyebabnya.

(a) Identifikasi Masalah

- Kurangnya bimbingan anak dari semua pihak

- Kurang pengawasan dari guru atau pihak sekolah secara intensif.

- Adanya pengaruh dari luar sehingga banyak siswa yang bertindak kurang disiplin.

(b) Etimologi

Berdasarkan penyebab masalah, peneliti menyimpulkan bahwa penyebab utama adalah: (1) Kurangnya perhatian dari guru atau orang lain yang kurang memperhatikan dan memberikan dorongan tentang 
motivasi belajar dan pembelajaran yang dilakukan sehingga kebanyakan siswa bersikap kurang disiplin; (2) Kurangnya kesadaran akan pentingnya belajar mengajar dan kebiasaan bertindak disiplin; dan

(3) Pengaruh antara individu dalam satu kelas yang kebanyakan terdapat siswa-siswa yang berpola pikir sama yakni mengabaikan tentang nilai kedisiplinan.

(4) Prognosis

Dari hasil diagnosis maka dalam langkah prognosis merupakan bagian dari diagnosis, untuk lebih jelasnya peneliti mengungkap masalah yang ada di kelas XI MIA 3 sebagai subyek penelitian. Apabila tidak mendapat bantuan pemecahan masalah terutama yang berhubungan dengan kurangnya kedisiplinan, maka siswa tersebut akan mengalami kerugian dan tindakan merugikan bagi dirinya dan lingkungannya.

Alternatif pemecahan masalah yang akan dilaksanakan adalah setelah dilakukan proses konseling kelompok berlangsung diprediksikan akan mengalami perubahan tingkah laku mereka.

\section{Konseling Kelompok (Treatment)}

Berdasarkan hasil observasi di kelas dan wawancara kepada guru yang mengajar di kelas tersebut dapat disimpulkan subyek sering melakukan tindakan kurangnya kedisiplinan. Oleh karena itu, diperkirakan ada beberapa faktor penyebab yang akan mempengaruhi yaitu faktor internal dan faktor eksternal. Faktor internal adalah pada diri subyek sendiri yakni kurang memahami tentang kedisiplinan.

Sedangkan faktor eksternal adalah faktor yang diperoleh dari luar, kemungkinan berasal dari lingkungan siswa sehingga dampak dari kekurangan-kekurangan itu dapat mengakibatkan prestasi belajar rendah dan kurangnya kedisiplinan dalam kehidupan sehari-hari.

Setelah proses Konseling kelompok selesai, siswa tersebut tidak sering berbicara sendiri pada waktu diberikan pelajaran, berpakaian rapi, tidak mengabaikan tugas guru dan tidak datang terlambat ke sekolah. Berarti dalam diri siswa itu timbul kesadaran dan pentingnya bertindak secara disiplin.

\section{Evaluasi dan Tindak Lanjut}

Siswa yang menjadi subyek dalam penelitian ini dapat mengurangi tingkah laku kurang disiplin dengan alternatif yang dikehendaki siswa dengan mengubah perilaku yang positif dan wajar. Sehingga siswa tersebut berkeinginan untuk bersikap secara disiplin. 
Efektivitas Konseling Kelompok Dengan Memanfaatkan Model Untuk Meningkatkan Kedisiplinan Siswa Kelas XI MIA 3 SMA Negeri 8 Surakarta Semester II Tahun 2014/2015 (Mawarto)

\section{Deskripsi Data dan Pembahasan Siklus I}

\section{Observasi}

Observasi terhadap perubahan perilaku siswa sebelum dan sesudah mendapat tindakan konseling kelompok. Observasi dilakukan dengan cara menganalisis gejala yang nampak sesuai dengan indikator yang ada.

Dari hasil observasi yang dilakukan terus menerus selama 2 minggu yaitu pada minggu kedua dan ketiga bulan April 2015, diketahui frekuensi dalam bersikap kurang disiplin sebelum diberikan konseling kelompok seperti tabel 4 berikut.

Tabel 4. Jenis dan Frekuensi Ketidakdisiplinan Hasil Observasi I

\begin{tabular}{|c|l|c|}
\hline No & \multicolumn{1}{|c|}{ Jenis perilaku yang diamati } & Frekuensi \\
\hline 1 & $\begin{array}{l}\text { Suka ramai/bicara sendiri jika diberikan } \\
\text { pelajaran }\end{array}$ & 18 siswa \\
\hline 2 & Mengabaikan tugas guru & 16 siswa \\
\hline 3 & Berpakaian kurang rapi & 10 siswa \\
\hline 4 & Datang terlambat masuk sekolah. & 8 siswa \\
\hline
\end{tabular}

Berdasarkan hasil observasi selama 1 bulan, diketahui bahwa frekuensi ketidakdisiplinan sesudah mendapat konseling kelompok tergambar dalam tabel 5 berikut.

Tabel 5. Perubahan Perilaku Setelah Siklus I

\begin{tabular}{|c|l|c|c|c|}
\hline No & \multicolumn{1}{|c|}{$\begin{array}{c}\text { Jenis perilaku yang } \\
\text { diamati }\end{array}$} & $\begin{array}{c}\text { Sebelum } \\
\text { Konseling }\end{array}$ & $\begin{array}{c}\text { Sesudah } \\
\text { Konseling }\end{array}$ & $\begin{array}{c}\text { Presentase } \\
\text { Frekuensi }\end{array}$ \\
\hline 1 & $\begin{array}{l}\text { Suka ramai/bicara } \\
\text { sendiri }\end{array}$ & 18 & 12 & $33 \%$ \\
\hline 2 & Mengabaikan tugas guru & 16 & 8 & $50 \%$ \\
\hline 3 & Berpakaian kurang rapi & 10 & 5 & $50 \%$ \\
\hline 4 & $\begin{array}{l}\text { Datang terlambat masuk } \\
\text { sekolah. }\end{array}$ & 8 & 4 & $50 \%$ \\
\hline \multicolumn{4}{|c|}{ Rata-rata persentase peningkatan } \\
\hline
\end{tabular}

\section{Evaluasi}

Evaluasi berarti pengukuran dan penilaian terhadap perubahan perilaku menyimpang terhadap sikap ketidakdisiplinan di sekolah pada siswa kelas XI MIA3 SMA Negeri 8 Surakarta. Cara melakukannya dengan observasi pada siswa untuk mengetahui perubahan perilaku siswa setelah diberikan konseling kelompok. Evaluasi pada tindakan I dilaksanakan pada 
minggu pertama bulan Mei 2015. Hasil evaluasi tindakan menggunakan standar minimal $(50 \%)$.

\section{Refleksi}

Refleksi adalah kegiatan bercermin diri. Dalam kegiatan refleksi peneliti mempertimbangkan hasil atau dampak dari tindakan yang telah dilakukan. Berdasarkan hasil observasi pada tindakan I ternyata subyek belum menunjukkan perubahan lebih dari 50\% (baru 45,75\%). Dengan demikian tindakan yang dilakukan oleh Guru peneliti belum berhasil.

\section{Siklus II}

Pelaksanaan tindakan II ini berarti pelaksanaan program konseling kelompok untuk meningkatkan kedisiplinan siswa pada siswa kelas XI MIA 3 SMAN 8 Surakarta tahun pelajaran 2014/2015.

Tabel 6. Matrik Tindakan Siklus II

\begin{tabular}{|l|l|l|l|}
\hline \multicolumn{1}{|c|}{$\begin{array}{c}\text { Rincian } \\
\text { Kegiatan }\end{array}$} & \multicolumn{1}{c|}{$\begin{array}{c}\text { Peran } \\
\text { Pembimbing }\end{array}$} & \multicolumn{1}{c|}{ Peran Subyek } & \multicolumn{1}{c|}{ Hasil } \\
\hline $\begin{array}{l}\text { Mengadakan } \\
\text { pendekatan } \\
\text { secara } \\
\text { persuasive }\end{array}$ & $\begin{array}{l}\text { Menciptakan } \\
\text { suasana harmonis, } \\
\text { hangat, penuh } \\
\text { keterbukaan }\end{array}$ & $\begin{array}{l}\text { Subyek menerima } \\
\text { pembimbing } \\
\text { dengan penuh } \\
\text { kepercayaan }\end{array}$ & $\begin{array}{l}\text { Terciptanya } \\
\text { hubungan yang } \\
\text { harmonis dan } \\
\text { hangat. }\end{array}$ \\
\hline $\begin{array}{l}\text { Mengungkap } \\
\text { masalah yang } \\
\text { dihadapi } \\
\text { subyek }\end{array}$ & $\begin{array}{l}\text { Bertanya tentang } \\
\text { masalah subyek }\end{array}$ & $\begin{array}{l}\text { Subyek } \\
\text { menjelaskan } \\
\text { permasalahan yang } \\
\text { dihadapi }\end{array}$ & $\begin{array}{l}\text { Masalah subyek } \\
\text { terungkap }\end{array}$ \\
\hline $\begin{array}{l}\text { Mengungkap } \\
\text { faktor } \\
\text { penyebab } \\
\text { masalah }\end{array}$ & $\begin{array}{l}\text { Bertanya tentang } \\
\text { hal yang berkaitan } \\
\text { dengan kejadian } \\
\text { atau masalah }\end{array}$ & $\begin{array}{l}\text { Subyek bercerita } \\
\text { tentang kejadian } \\
\text { sebelum masalah } \\
\text { terjadi }\end{array}$ & $\begin{array}{l}\text { Terungkap latar } \\
\text { belakang masalah } \\
\text { subyek }\end{array}$ \\
\hline $\begin{array}{l}\text { Menerapkan } \\
\text { konseling } \\
\text { kelompok }\end{array}$ & $\begin{array}{l}\text { Memberikan } \\
\text { contoh kepada } \\
\text { subyek }\end{array}$ & $\begin{array}{l}\text { Subyek mempunyai } \\
\text { semangat baru }\end{array}$ & $\begin{array}{l}\text { Subyek bersedia } \\
\text { untuk } \\
\text { meningkatkan } \\
\text { kedisiplinan }\end{array}$ \\
\hline $\begin{array}{l}\text { Mengakhiri } \\
\text { pertemuan }\end{array}$ & $\begin{array}{l}\text { Menutup } \\
\text { konseling } \\
\text { kelompok, } \\
\text { menyimpulkan }\end{array}$ & $\begin{array}{l}\text { Subyek akan } \\
\text { berusaha merubah } \\
\text { lebih disiplin }\end{array}$ & $\begin{array}{l}\text { Perubahan/ } \\
\text { peningkatan } \\
\text { subyek. }\end{array}$ \\
\hline
\end{tabular}

Pelaksanaan tindakan II ini ada dua hal pokok yang dilakukan yaitu: a) Menyempurnakan kegiatan pada tahap I, dan b) melaksanakan konseling kelompok secara lebih intensif. Langkah-langkah tindakan II dapat dilihat pada tabel 6. Fokus pelaksanaan tindakan II adalah untuk mengatasi perilaku menyimpang yaitu ketidakdisiplinan siswa di sekolah dalam mengikuti pelajaran di kelas. Sesuai dengan teknik konseling yang digunakan, yaitu konseling kelompok maka pelaksanaan konseling 
Efektivitas Konseling Kelompok Dengan Memanfaatkan Model Untuk Meningkatkan Kedisiplinan Siswa Kelas XI MIA 3 SMA Negeri 8 Surakarta Semester II Tahun 2014/2015 (Mawarto)

dilakukan secara kelompok dengan menentukan aspirasi atau harapan subyek agar dapat mengatasi masalah yang ada secara lebih baik dalam upaya peningkatan kedisiplinan. Adapun pelaksanaan tindakan II dilakukan pada minggu ke 3 bulan Mei 2015.

\section{Deskripsi Data dan Pembahasan Siklus II}

\section{Observasi}

Observasi adalah pengamatan dan pencatatan terhadap perubahan perilaku siswa sebelum dan sesudah mendapat tindakan konseling kelompok. Observasi dilakukan dengan cara menganalisis gejala yang nampak sesuai dengan indikator yang ada. Untuk mengetahui hasil observasi secara jelas, perlu disusun lembar observasi yang memuat reka hasil perubahan yang ada.

Dari hasil observasi yang dilakukan dengan cara berselang-seling dengan tindakan konseling kelompok selama 1 minggu yaitu pada bulan Mei dan minggu ke-3 sampai dengan Mei minggu ke-4 diketahui frekuensi tindakan kurang disiplin sebelum diberikan konseling kelompok pada tindakan II ini adalah sebagai berikut.

Tabel 7. Hasil Observasi Tingkah Laku Subyek Pada Tindakan II Frekuensi Rata-Rata Tiap Minggu

\begin{tabular}{|c|l|c|}
\hline No & \multicolumn{1}{|c|}{ Jenis perilaku yang diamati } & Frekuensi \\
\hline 1 & $\begin{array}{l}\text { Suka ramai/bicara sendiri jika diberikan } \\
\text { pelajaran }\end{array}$ & $12 \mathrm{kali}$ \\
\hline 2 & Mengabaikan tugas guru & $8 \mathrm{kali}$ \\
\hline 3 & Berpakaian kurang rapi & $5 \mathrm{kali}$ \\
\hline 4 & Datang terlambat masuk sekolah. & 4 kali \\
\hline
\end{tabular}

\section{Evaluasi}

Evaluasi yaitu untuk mengukur dan menilai terhadap perubahan perilaku kedisiplinan pada kelas XI MIA3 SMAN 8 Surakarta tahun pelajaran 2014/2015 dengan cara melakukan observasi untuk mengetahui perilaku siswa setelah diberikan konseling kelompok.

Hasil dari treatment dan peningkatan beberapa tingkah laku, jika diprosentasekan kurang lebih 77,5\% siswa tersebut mengalami perubahan bahkan penurunan frekuensinya. Melalui konseling kelompok juga bermanfaat bagi siswa, menyadari betapa pentingnya kedisiplinan yang berlaku di sekolah.

Tabel 8. Perubahan Perilaku Sebelum dan Sesudah Mendapat 
Konseling kelompok Tindakan II

\begin{tabular}{|c|l|c|c|c|}
\hline No & \multicolumn{1}{|c|}{$\begin{array}{c}\text { Jenis perilaku yang } \\
\text { diamati }\end{array}$} & $\begin{array}{c}\text { Sebelum } \\
\text { Konseling }\end{array}$ & $\begin{array}{c}\text { Sesudah } \\
\text { Konseling }\end{array}$ & $\begin{array}{c}\text { Presentase } \\
\text { Frekuensi }\end{array}$ \\
\hline 1 & $\begin{array}{l}\text { Suka ramai/bicara sendiri, } \\
\text { jika diberikan pelajaran }\end{array}$ & $12 \mathrm{kali}$ & 3 & $75 \%$ \\
\hline 2 & Mengabaikan tugas guru & $8 \mathrm{kali}$ & 0 & $100 \%$ \\
\hline 3 & Berpakaian kurang rapi & $5 \mathrm{kali}$ & 2 & $60 \%$ \\
\hline 4 & $\begin{array}{l}\text { Datang terlambat masuk } \\
\text { sekolah }\end{array}$ & $4 \mathrm{kali}$ & 1 & $75 \%$ \\
\hline \multicolumn{4}{|c|}{ Rata-rata peningkatan prosentase } & $77,5 \%$ \\
\hline
\end{tabular}

\section{Refleksi}

Refleksi adalah kegiatan untuk mengoreksi diri atau bercermin diri, sehingga kegiatan ini peneliti mengevaluasi hasil dari tindakan yang telah dilakukan. Berdasarkan hasil observasi pada tindakan II ternyata subyek menunjukkan perubahan lebih dari 50\% yang ditargetkan menjadi 77,5\% . Dengan demikian tindakan yang dilakukan oleh guru pembimbing (peneliti) dikatakan berhasil.

\section{PENUTUP}

\section{Simpulan}

Berdasarkan evaluasi pada tindakan I dilaksanakan pada minggu pertama bulan Mei 2015, maka hasil evaluasi akhir tindakan berdasarkan standar minimal (50\%) dan tujuan setiap tindakan bahwa hanya menunjukkan perubahan $45,75 \%$ ke arah positif atau lebih baik, maka tindakan yang dilakukan oleh pembimbing sebagai peneliti dikatakan belum berhasil.

Pada evaluasi tindakan II yang dilaksanakan pada minggu pertama bulan Juni 2015 maka hasil evaluasi akhir tindakan tersebut standar minimal (50\%) dari tujuan setiap tindakan bahwa subyek menunjukkan perubahan lebih dari $50 \%$ ke arah atau lebih baik yakni dengan nilai prosentase $77,5 \%$, maka tindakan yang dilakukan oleh peneliti dikatakan berhasil.

Berdasarkan hasil penelitian tindakan tahap II, siswa yang kurang disiplin dapat dibantu dengan konseling kelompok. Siswa yang mempunyai perilaku kurang disiplin dipengaruhi oleh faktor internal dan eksternal. Pada siswa yang kurang memiliki kedisiplinan, setelah proses konseling kelompok, subyek menjadi lebih mengarah pada perubahan yakni meningkatnya kedisiplinan di sekolah. Perubahan positif perilaku subyek nampak dalam bentuk penurunan frekuensi ketidakdisiplinan. Setelah dilakukan konseling kelompok prosentase perubahan 
Efektivitas Konseling Kelompok Dengan Memanfaatkan Model Untuk Meningkatkan Kedisiplinan Siswa Kelas XI MIA 3 SMA Negeri 8 Surakarta Semester II Tahun 2014/2015 (Mawarto)

frekuensi yang standar minimal (50\%) menjadi lebih baik dapat mencapai 77,5\%.. Dengan demikian, berarti proses konseling kelompok berhasil dengan efektif untuk membantu meningkatkan kedisiplinan siswa.

\section{Saran}

Saran yang peneliti berikan kepada rekan-rekan guru BK untuk lebih meningkatkan kualitas layanan bimbingan dan konseling khususnya konseling kelompok, sehingga memiliki kesiapan dan jika ada kesulitan dan atau kelemahan dalam pelaksanaannya dapat diatasi dengan baik lewat budaya penelitian bimbingan dan konseling.

\section{DAFTAR PUSTAKA}

Anwar Sutoyo, 2009. Pemahaman Individu 1. Semarang: FIP UNNES

Arisandi, 2011. Pengertian Disiplin dan Penerapannya Bagi Siswa, (Online), dalam (Arisandi.com/pengertian-disiplin-dan-penerapannya-bagi-siswa/, diakses 23 November 2013).

Azhar, 2011. Pengaruh Disiplin Belajar di rumah Terhadap Prestasi Belajar Siswa di SMA Kabupaten Deli Serdang. Jurnal Ilmiah Pendidikan Tinggi. No.3 Vol.1 Oktober 2011

Imam Tadjri, 2014. Penelitian Tindakan Bimbingan dan Konseling. Semarang: Universitas Negeri Semarang.

M. Edi Kurnanto, 2013. Konseling Kelompok. Bandung: Alfabeta.

Mulyasa, 2003. Mendidik Dan Menerapkan Disiplin Pada Anak Prasekolah. Bandung. Rosda Karya.

Semiawan, Conny R., 2009. Penerapan Pembelajaran pada Anak. Jakarta: Indeks.

Suyadi.2009. Permainan Edukatif yang Mencerdaskan. Jogjakarta: Power Books.

Tim Kemendikbud, 2013. Materi Pelatihan Guru Implementasi Kurikulum 2013. Bimbingan Konseling. Jakarta: Kementerian Pendidikan dan Kebudayaan RI.

Wiyani, Novan Ardy, 2013. Bina Karakter Anak usia Dini. Ar Ruzz Media.Yogyakarta. 